\title{
Tracing maize in the Slovenian regions, sixteenth-eighteenth century. An interpretive historiographical essay
}

\author{
Aleksander Panjek \\ University of Primorska, Faculty of Humanities
}

\section{Introduction}

The aim of this article is to outline the state of the art in the field of research on maize diffusion in the Slovenian regions, from its earliest appearance until the end of the eighteenth century. In doing so, it concentrates on a period about which our knowledge is not satisfactory yet, due to a lack of in-depth and specifically focused research, but also due to scattered and mostly incidental mentions in the primary sources. With the first decades of the nineteenth century, the situation becomes much clearer, since we may rely on the systematic mentions contained in the Austrian Franciscean Cadastre (1819-1830), but at the same time it is already mature, in the sense that maize is quite well known and widespread.

The real breakthrough in the spread of both new plants [maize and potato] came after three consecutive poor harvests in 1815-17. At that time, potatoes were fully established in Carniola; maize was widely spread in Carinthia and in the Province of Gorizia, while in Styria both cultures were. It was only after these changes in the cultivation of potatoes and maize that the catastrophic famine disappeared, which had often affected the population in the Slovenian lands (Gestrin 1969b, 66).

Our interest is to reconstruct the times and the ways by which such results had been reached. In the attempt to fulfil our goal, we will base on ex- 
isting historical literature, which is mostly not recent, revealing a scarce interest in this topic over the last decades. The article starts by presenting the situation as shown by the earliest known mentions of maize in the wider area between the eastern Alps, the Adriatic Sea and the Pannonian Plain. It continues by reconstructing the diffusion of maize as a crop, a foodstuff, and a trade good, proceeding through half-century timespans and distinguishing by different provinces or micro-areas, in order to get a picture of the progression and of the provenience of maize diffusion. In some cases, the reconstruction overlaps today's Slovenian boundaries to better cover the wider Slovenian ethnic area, but more so to achieve a better comprehension and a fuller picture of the dynamics of diffusion. ${ }^{1}$ In the end, I integrate existing interpretations with some preliminary new ones, outlined based on the achieved results.

\section{Surrounded by early mentions of maize in the eastern}

\section{Alpine-Adriatic area}

The earliest mention of maize in the area, known so far, dates back to the 1559, when an unknown amount of seeds was sent for test planting to a village (Kraig) near the town of Sankt Veit an der Glan in Central Carinthia. Although this should mean that maize was "a great rarity" there at that time (Brunner 1994, 7, citing Wadl), already a dozen years later (1572) in a village near the Styrian capital of Graz (Hardt, Thal parish) the earliest known proof of maize cultivation was detected. Two peasant women were sent on trial for having illicitly picked up 150 branches they used to support maize seedlings, or literally "Turkish grain or what for an odd seed they planted" (Brunner 1994, 9-10). The next year some tithe registers in South Tyrol started mentioning maize (1573-1585), which must have reached the area from the Italian regions (Brunner 1994, 7, Sandgruber 1982, 45); however, we have already moved a bit too far from the Slovenian regions. Much closer is the mention of maize in $\mathbf{1 6 0 2}$ in a register of grain prices from the town of Gradisca d'Isonzo in the County of Gorizia (Valenčič 1970, 258). One might say that the Slovenian regions were very closely surrounded by these earliest mentions - that is to the northwest (Carinthia), northeast (Styria) and southwest (County of Gorizia).

1 I wish to thank Peter Teibenbacher who very kindly handed me the literature on Austrian Styria used in this article. 


\section{The first half of the seventeenth century:}

\section{clear traces in the east, much less so in the west}

Information about maize in the first half of the seventeenth century is quite rare and interpretations sound rather vague. Since we have just mentioned the County of Gorizia, we will proceed from there, that is from the west towards the east. Carlo Morelli, who reorganized the county's archives in the eighteenth century and consequently had a very good insight into its history, when mentioning the 1629 famine commented how "the province had the disadvantage that the Turkish grain, which today [around 1780] serves as the main nourishment for the common people, was almost unknown in our area until the middle of that century" (Morelli 1855, II, 144-145). His judgment may be at least partially confirmed by the fact that maize is not mentioned among the landlords' revenues in most of the county in the 1620 s and 1630 (Panjek 2011). Simon Rutar's mention is not helpful to define a precise chronology for the mountain area in the Upper Isonzo Valley, as he writes that "following the example of the Friulians, who began cultivating maize already around 160o, the people from the Tolmin area took it up as well and started sowing it increasingly from year to year" (Rutar $1882,150)$. In a trial for misdeeds that happened in the Adriatic port town of Trieste in 1614, a person is mentioned with the nickname "Cinquantin". Seeing that it was the name of a fast-growing sort of maize, this may be interpreted as a quite clear sign that it was known well enough for someone to be named after it. On the other hand, in nearby Istria, maize would not be cultivated until 1650 (Ivetic 1999, 81). All in all, we may conclude that although maize was undoubtedly known (Gradisca 1602, Trieste 1650), in the western and south-western Slovenian regions its diffusion was seemingly still quite limited throughout the first half of the seventeenth century. Information differs as far as the extreme north-western Alpine area is concerned, since in the Gail Valley (Ziljska dolina, Carinthia) maize was well known since the early seventeenth century (Sandgruber 1982, 46).

With a swift move to the east, we encounter various confirmation that maize continued to be quite well known in Styria also after its early documented appearance among the peasants near Graz. In 1608, maize is mentioned in the Milling Rules of Graz (Grazer Müllerordnung), although in last place among all the grains (Sandgruber 1982, 47), while in 1636, a small quantity is mentioned in the probate inventory of a peasant in the Stainz

2 Steiermarkisches Landesarchiv, Innerösterreichische Hofkammer; due to the epidemic I was not able to double check the complete signature. 
manor, located in the same part of Styria, southwest of Graz (Brunner 1994, 11). These, more recent findings, confirm earlier writings about maize being demonstrably present there since the first half of the seventeenth century, the main area of its distribution being, from the very beginning, the present-day south-western Austrian Styria (Pferschy 1976, 27), that is the area closest to Slovenia, although I found no explicit mention of maize in the present-day Slovenian Styria in this period. What seems particularly remarkable is that in this part of Styria maize is found among peasants early (and repeatedly so).

On the other hand, we may notice that none of the above-cited documented mentions originated from the central Slovenian region, the Duchy of Carniola, nor from today's territory of Slovenia. All of them are located on the outskirts of the (then and/or present) Slovenian ethnic area. In fact, in the poorhouse of Ljubljana, the capital town of Carniola, there was no maize on the menu in 1638 (nor in 1718; Makarovič 1986 58-59). For a wider picture, even Makarovič, who wrote a thematic article about food in Slovenia in the seventeenth century, mentions maize only once, namely in the second half of that century, although he based his work on numerous sources and mentioned several different types of grain. Whether such a 'state of the art' derives from the researchers' paying less attention to this subject, from a lack of preserved archival documents, or from the factual absence of maize is not completely clear. In any case, if maize was already present in the first half of the seventeenth century, it seems that it has to be sought in the south-western (Littoral) and north-eastern (Styria) regions and not in central Slovenia (Carniola).

\section{The second half of the seventeenth century:}

\section{diffusion pattern on a local basis, seemingly more in the east}

For the next timespan we will again proceed from the west to the east, but in this case, we will not overlook Carniola, since we may find mentions there, too. Another difference compared to the previous period is that I was not able to find any explicit and documented information about maize in the western Slovenian areas for the second half of the seventeenth century, except for the indirect and rather vague ones already mentioned in the previous paragraph, indicating that it started to spread after the mid-century. An additional piece of information is that while grain import through the Adriatic port towns of Trieste and Rijeka was increasing in the bad harvest years of the seventeenth century, maize is not mentioned among such im- 
ports (Valenčič 1977, 31, 48-9). This may mean that maize was not yet available in the Adriatic Sea trade or that it was not yet used locally as food for the hungry and poor, thus not attracting its import.

No Slovenian historian can write about this period without referring to Valvasor, whose writings reflect the situation in the mid-decades of the second half of the seventeenth century, and we will make no exception here. He reports that within Carniola maize was cultivated only in some places, mostly in southern and western Carniola (Dolenjska, Kočevska; Notranjska). Its yield was 1:30 and it was also used to bake bread (Britovšek 1958/9, 128; Valenčič 1970, 259). Notranjska, the south-western part of Carniola, represents the hinterland of the Littoral region and may well be included in the south-western part of Slovenia, rounding up our picture of this geographical segment. According to Britovšek, maize here "naturalized faster" than elsewhere in Carniola and "they started including it in the everyday food already at the end of the seventeenth and the beginning of the eighteenth century" (Britovšek 1958/59, 132). Another part of Carniola where maize appears in the literature concerning the second half of the seventeenth century is its southern areas (Dolenjska, Kočevska, Bela Krajina, Metlika). Again basing on Valvasor, Makarovič wrote that at that time "in Dolenjska they did already cultivate maize and used to mix it with wheat to make a good maize bread" (Makarovič 1986, 62). Although with a less precise chronology, we may also read that in the Metlika area "the peasants have gotten to know maize well already since the seventeenth century" (Britovšek 1964, 207).

For an overall picture, we will rely once again on Britovšek, the author of one of the most documented works on Slovenian early modern agrarian history: "In general, we may affirm that maize in the seventeenth century was still a rarity in Carniola. It was restricted to various gardens and it is not mentioned in the fields". Concurrently, in the second half of the seventeenth century maize crops are "very rarely" mentioned in the accounting books of manors and monasteries, as well as in landlords' probate inventories (Britovšek 1964, 205). If this is the 'large picture', we have noticed so far that the situation was a bit more varied, especially if we expand the view to the whole of the western Slovenian regions. Maize was apparently gaining ground in the County of Gorizia, in the Trieste area, in Notranjska, as well as in some locations of southern Slovenia. Its cultivation was seemingly still far from being widespread, but in some areas, maize had made its 
way into the peasants' plots and to their dining tables, surely faster than in the noblemen's barns.

As far as the present-day Slovenian Styria is concerned, mentions of maize by Slovenian historians refer generally to the seventeenth century as the time of its appearance; even for the second half of the century there is no clear evidence in the literature I was able to review. The most likely confirmation of its presence is a statement by the provincial estates of Styria (that governed in the Slovenian area as well), which stated in 1670 that the peasants lived on maize, buckwheat and millet the whole year round, because the heavy grains were used to pay their dues (Sandgruber 1982, 47; Brunner 1994, 12). In fact, discussing Slovenian Styria, Valenčič mentions how maize was "considered an important part of popular nutrition already at the end of the seventeenth century" (Valenčič 1970, 259).

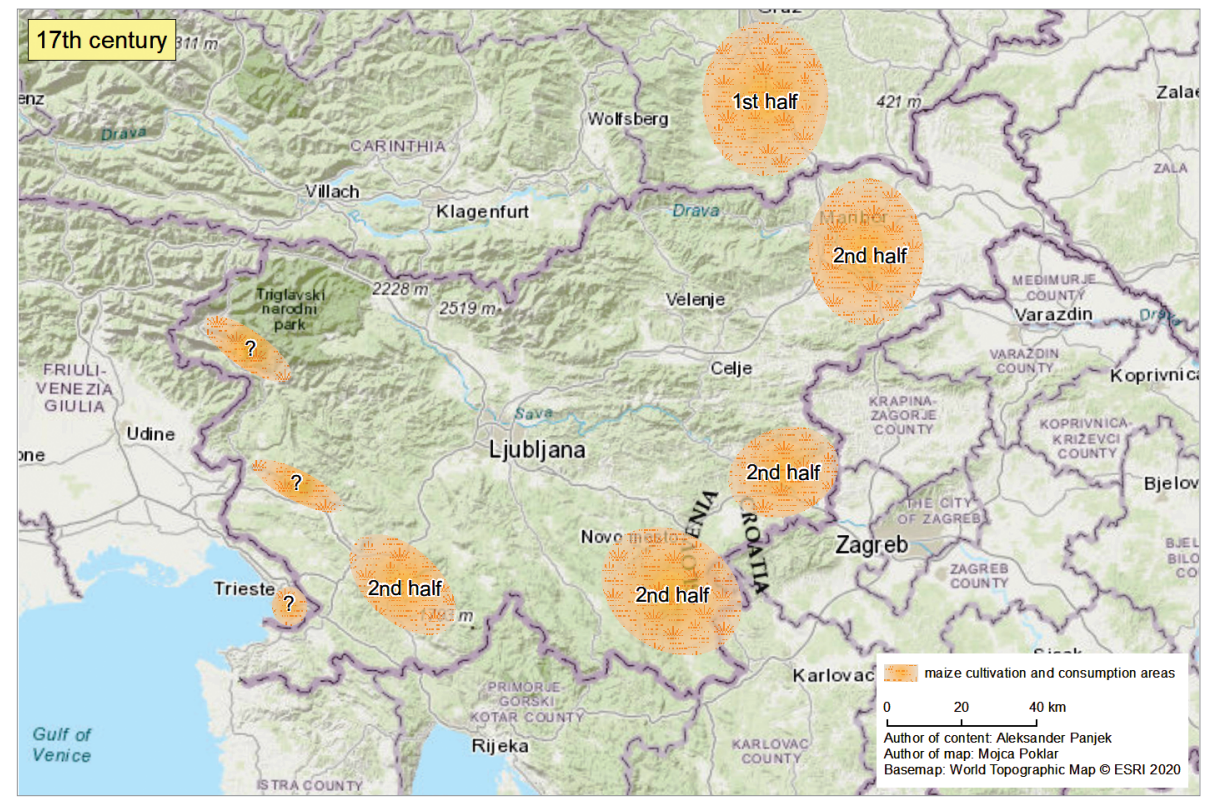

Map i. Maize diffusion in the seventeenth century

The signs of maize in the present-day Austrian Styria are more numerous, and again one wonders if this might not be a consequence of a lack of specific research rather than a reflection of historical reality. In fact, in addition to the already mentioned provincial parliament's statement, quite numerous other proofs may be added, especially of maize in peasants' pro- 
bate inventories in the already known area southwest of Graz (Brunner 1994, 11-12).

Nevertheless, interpretations by Austrian historians are somewhat contradictory or at least cautious. On the one hand, we may read that maize was generally cultivated and appreciated as food, but that it was still not the main crop (Brunner 1994, 11-12). On the other hand, basing on accounting books, it is not possible to demonstrate that maize was cultivated in larger amounts before the beginning of the eighteenth century anywhere in Austrian Styria (Sandgruber 1982, 47).

\section{The first half of the eighteenth century: a seemingly sudden booming}

Our review now returns to the western regions and starts from there towards the east. After the lacking or at least loose historians' statements regarding the presence of maize in the western Slovenian areas in the first and second half of the seventeenth century (except for Carinthia), in the following century it seems to suddenly become rather widespread in some areas, especially by the Adriatic coast. Around Trieste, for example, "already in the first half of the eighteenth century, maize was in first place among all the crops" (Britovšek 1964, 210). In nearby Istria, we find it especially in the area around the coastal town of Koper and, more generally speaking, in the wetlands of northern Istria (Ivetic 1999, 81), i.e. in today's Slovenian territory and very close to Trieste. Quite the same may be said about the other side of the Istrian Peninsula. In the surroundings of Rijeka in the first half of the century, where maize "very quickly" gained first place among the crops, as is shown for example by the peasants of St Augustin's monastery, who sowed mostly maize and made it their everyday food by the mid-eighteenth century. "Quite a lot" of maize was to be found in some areas of inland Istria, too, such as the lands belonging to the monastery of St Peter in the Woods and the Pičen Diocese. At the same time, in the nearby Brkini area, the peasants of the Podgrad manor were cultivating as much maize as wheat (Britovšek 1964, 210).

Surprisingly, somehow, we have no explicit and documented proof of maize cultivation or consumption in the westernmost County of Gorizia, apart from a few generic mentions regarding the entire seventeenth and eighteenth centuries already cited above (Rutar 1882, 150; Gestrin 1969a, 3). On the contrary, it is possible to report a few mentions of maize in the south-western part of Carniola, that is in Notranjska, located east of the 
County of Gorizia and north of Istria. Here we may find maize cultivated in the fields in the first half of the eighteenth century, although in a "still insignificant" quantity; in fact, it would not expand beyond the climatically more favourable areas throughout the century. Nevertheless, among all the areas of the Duchy of Carniola it was precisely in the Notranjska and Dolenjska regions that maize became most present by the mid-eighteenth century, based on the Theresian cadastres, "which are the first to provide maize statistics as somewhat reliable statistical evidence on maize" on landlords' and peasants' land (Britovšek 1964, 206, 210).

It is now time to turn towards Dolenjska, the south of Slovenia, although there too maize crops were still "very small" until the mid-eighteenth century. In some circumscribed areas (Mokrice), "maize was cultivated by the vast majority of peasants, but the crops were very small" (Britovšek 1958/59, 130).

In general, we may say that in the mid-eighteenth century, maize was already widespread in the Dolenjska region, but it still remained a garden crop and rarely succeeded in being classified as a field crop. Maize crops were so exiguous that they did not significantly affect the diet of the peasant population. [...] Compared to other cereals, maize was in the last or penultimate place. In fact, it was to be found more on landlords' than on peasants' land, and it was used primarily for poultry feeding, while peasants used to plant it only at the edges of cabbage orchards (Britovšek 1964, 206, 209).

Much more than in the Dolenjska region, maize was most widespread within southern Carniola (and Slovenia) in the first half of the eighteenth century in the nearby Bela Krajina area. On the demesne land of the Metlika commandery, maize was the third most cultivated crop (with a yield of 1:40 to 1:50). There, maize was indeed widespread among peasants as well, both in their fields and on their tables, since it already entered their everyday menu. Most of all it was present in the Podbrežje manor, where some peasants were sowing up to 30 litres of maize seeds (Britovšek 1958/59, 130; Britovšek 1964, 207). In the nearby Kočevje area it was much less sown, and mostly as an orchard crop (Britovšek 1964, 208).

On the other side of the Slovenian lands, in Styria to the northeast, in the first half of the eighteenth century, evidence is unambiguous. In the area south of Graz (today's Westseiermark) already observed above, short- 
ly after 1700 maize gained additional importance in nutrition, its quantities increasing significantly in peasant probate inventories, in which it became the most recorded cereal by the mid-eighteenth century (Stainz manor, 1733). It may also be found in the form of mixed maize and wheat flour (Thal parish), signalling that it was meant for human nutrition and not as fodder (Brunner 1994, 11-12). Still, this evidence places us outside today's Slovenian Styria, but official administrative documents undoubtedly state that maize was present there, too. In 1732-1733, conflicts arose about peasants' tithes - levies on maize to their landlords. Some historians mention that the ruler issued a decree ordering the payment of such a tithe (in fact, it referred to the twentieth part of the harvest), while others mention its abolition. Anyhow, we may abide by Gestrin's and Sangruber's interpretation that the decree and the related conflicts prove there was "a considerable amount of maize cultivation in this region during the first half of the eighteenth century", and that by 1733 maize was widespread enough to trigger such conflict (Gestrin 1969a, 3; Sandgruber 1982, 47). After it was exempted from the tithe in 1733, maize was cultivated everywhere in Central and Lower Styria (Mittel- und Untersteiermark), as Brunner writes basing on Fritz Posch (Brunner 1994, 9). Central and Lower Styria means the southern part of today's Austrian Styria (that is the area around and south of Graz reaching the Slovenian border) and today's Slovenian Styria. Around 1750, dishes such as türkische Koch and Türkensterz, which could be translated as maize mash and maize polenta, ${ }^{3}$ were already defined as "popular food" (ordinary people's nourishment) in Styria (Sandgruber 1982, 47; Brunner 1994, 12).

\section{The second half of the eighteenth century:}

the final conquest of ordinary people's dishes

Returning to the west, I could not find an earlier and clearer evidence of maize in the peasant diet than the contract regarding the yearly alimonies in favour of the widow Marina Sivic in the Classical Karst near Trieste, dated 1753. This date can be considered mid-eighteenth century and most probably indicates that in this area maize entered the dishes of the common people already in the first half of the century. In Marina's case, among the five different cereals she received, maize was in second place, representing one quarter of the total quantity (Table 1). 
Table ı. Yearly alimonies (cereals only), Marina Sivic (Skopo - Križ / S. Croce), 1753

\begin{tabular}{|c|c|c|}
\hline Cereals & Litres & Percentage \\
\hline Wheat & 30.8 & $10 \%$ \\
\hline Rye & 30.8 & $10 \%$ \\
\hline Spelt & 92.4 & $30 \%$ \\
\hline Buckwheat & 77.0 & $25 \%$ \\
\hline Maize & 77.0 & $25 \%$ \\
\hline Total & 308.0 & $100 \%$ \\
\hline
\end{tabular}

Source: Panjek 2008, 26.

When describing "production and trade" in his long and detailed report on the Gorizia and Gradisca counties of 1775, the chief of the local administration began thus: "The productions of the region are as follows: 1) the various cereal crops, such as wheat, maize, rye, oats and barley" (Cavazza et.al. 2003, 174). Maize was in second place among the cereals, signalling its importance. The observations of two contemporary writers are completely in line with this, even accentuating the importance of maize as a popular foodstuff. In his book Clima Goritiense (1781) the physician Anton Muznik wrote that in the Gorizia area "great quantities" of maize were cultivated and that besides vegetables, bread and wine, the people of the valleys predominantly ate "polenta, a thick porridge seasoned with salt, butter, bacon", made of maize (Fakin Bajec 2015, 25, 28, citing Muznik). This means that maize dominated the dishes also in the larger Vipava and Soča valleys and in the smaller mountain valleys in the area. Balthasar Hacquet, whose work describes the situation in the last decades of the eighteenth century, confirms that. Writing about the Vipava Valley and Idrija, he mentions how "the food consists of the so-called polenta of Turkish maize; they consume little meat", whereas because of the stony and Alpine landscape only in the "narrow valleys some maize can be cultivated" (Hacquet 1801, 79, 82). Therefore, maize had conquered even the plots in the mountain valleys, not only the plain around Gorizia.

On the other side, east of Trieste, the cultivation of maize spread in Istria along its western Adriatic coast towards the south (present-day Croatia) during the second half of the eighteenth century, or after 1763 in particular (Ivetic 1999, 81). Hacquet, who visited the area in those decades (for the first time in 1774), confirms this also for maize consumption. From his description, we may understand that he referred to central and northern Istria, including the surroundings of Trieste, in particular the coastal 
area but at least in part inland Istria, too, especially as far as maize is concerned. "The daily diet is mostly polenta, and since the wine is sold at lower prices, it is the refreshing drink of the poor countryman. The inhabitants of the coast do not lack good fish, among which tuna fish (Tonina) is common, but the sardines (Sardellen) surpass all others" (Hacquet 1801, 42).

For the other areas of western and southern Slovenia (Notranjska, Dolenjska and Bela Krajina) we must rely on the indications mentioned in the previous paragraph, registering the presence of maize both as a crop and as a foodstuff by the mid-eighteenth century and afterwards. On the other hand, the diffusion of maize in the rest of Carniola was still in its beginnings or not even that. In the Alpine area of north-western Carniola, Gorenjska, "due to the lack of more resistant maize species, the new plant was not established until the second half of the eighteenth century [...]; only then did it begin to take root in larger amounts" (Britovšek 1964, 211). This situation echoes that of the nearby Carinthia, situated to the north, although there maize was known early and seems to have spread a bit faster. ${ }^{4}$ "From the mid-eighteenth century onwards, maize spread along the Drava River into Lower Carinthia and the lateral Alpine valleys; therefore, the prevalence of maize in Carinthia cannot be discussed until the end of the eighteenth century (Sandgruber 1982, 46).

In the rest of Carniola, we find no trace of maize whatsoever. It seems a telltale sign that even the administration of the large quicksilver mine in Idrija, where a relevant concentration of wage workers lived, which used to buy the grain supplies for its miners from the provincial estates of Carniola, was not provided with any maize at least until 1780 (Valenčič 1977, 36-8). Since those provisions came from the Carniolan landlords' granaries, this can only mean there was no relevant maize production. In the tables of cereal prices in the capital of Ljubljana, maize appears for the first time as late as in 1795 (Valenčič $1977,88,157-160$ ). As a final piece of evidence, when describing nutrition in Carniola in the last decades of the eighteenth century, Hacquet does not mention maize (nor potato), but only buckwheat, rye, sauerkraut and turnip (Hacquet 1801, 20-21).

As Vlado Valenčič, the author of the most complete history on grain trade in Carniola and of other works on Slovenian agricultural history, put it shortly, maize in Carniola "until the end of the eighteenth century did not spread to a larger extent. Relatively more maize was sown in Styria" (Valenčič 1970, 259). Yet again, mostly Austrian scholars provide informa- 

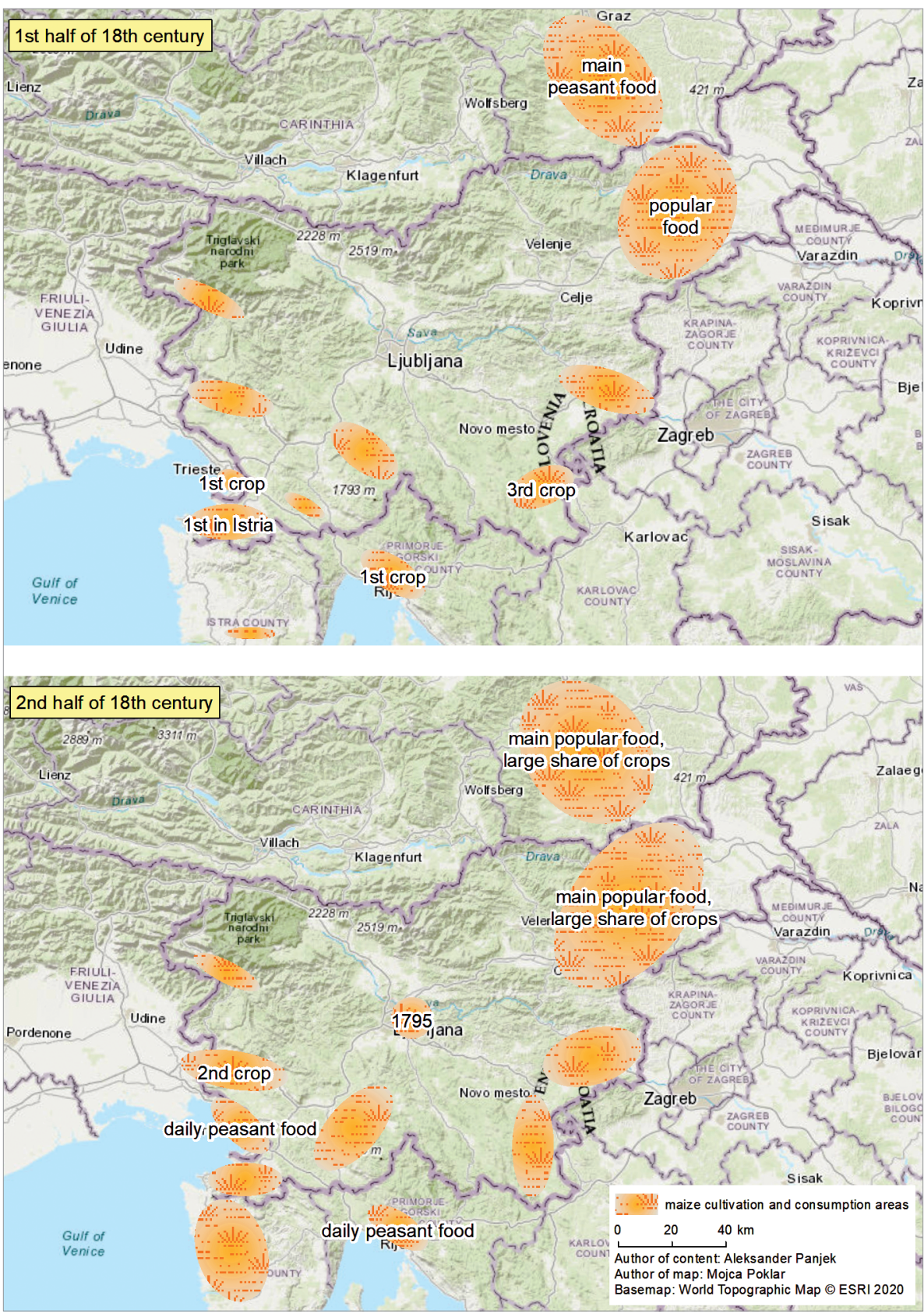

Map 2. Maize diffusion in the eighteenth century. 
tion on Styria that is more precise. We will stick to Roman Sandgruber, the author of a still fundamental work on consumption history in Austria, who had a broad insight and was therefore able to evaluate the situation in comparative terms. Sandgruber found Burger's evaluation, according to which, at the end of the eighteenth century, maize occupied a quarter of the arable land in the Graz district (present-day Austria) and slightly less in the Maribor and Celje districts (present-day Slovenia), to be exaggerated, since later data from the early nineteenth century testify to much lower numbers. Nevertheless, in his opinion, it was in the late eighteenth century that maize reached the position of the most important basic cereal in central and southern Styria (Mitte- und Unterland, present-day Austria and Slovenia). Maize was then an exclusively peasant foodstuff used to bake bread, since the citizens of Graz did not eat it, but instead used it as animal fodder (Sandgruber 1982, 47). We may conclude with a look into the peasant probate inventories of the repeatedly cited area south-west of Graz, in which, towards the end of the eighteenth century, maize took up from one fifth to one third of all cereals (Brunner 1994, 11).

\section{Maize trade in the eighteenth century: import, provenience and trade centres}

We have so far concentrated on maize cultivation and consumption only, but to evaluate its diffusion, as a foodstuff in particular, one must not disregard trade. Up to and including the sixteenth century, the Duchy of Carniola was a cereal exporter and would not import it. In the seventeenth century, mostly in the second half, grain imports in Carniola through the Adriatic ports of Trieste and Rijeka increased, although they were still "exceptional", limited to bad harvest years and to its karstic areas (south-western and southern Slovenia) (Valenčič 1977, 31, 48-9).

Among such imports, maize was not mentioned until the first decades of the eighteenth century. In fact, a description of the economic situation in Carniola in 1712-1721 reports that, especially in bad harvest years, maize started to be imported "from Italy, Dalmatia and the Balkan regions" through Trieste and Rijeka. Since a livelier sea trade was developing there after both towns had been declared duty-free ports by the Austrian ruler, in the first decades of the century "larger quantities of maize were arriving from the Republic of Venice, the Romagna region [Papal States] and Turkish lands". Such maize was then sold mostly in the Classical Karst hinterland, but also to Dolenjska (the Ribnica area in particular) and even to 
Gorenjska, meaning that its buyers were to be found "in the less fertile areas" of Carniola (Valenčič states also that maize was not yet cultivated in the region). These imports seem to have quickly achieved an important role in granting the subsistence of the rural population especially in south-western Slovenia in years of scarcity. In fact, while the provincial estates of Carniola in 1727 asked the ruler to prohibit maize imports, seeking protection for landlords' grain from such a concurrence, the ruler's representative in the duchy (Vizedom) immediately commented that "had maize not have arrived from the Papal States to Rijeka and Trieste, there would have been famine in the Classical Karst and Pivka" (Notranjska region). The provincial estates insisted on an import ban and tried to justify such a request, among other things, with the fact that "maize was partly imported from Turkish lands". Nevertheless, imports continued, as was the case in the bad harvest year of 1740, when grain prices rose high in Carniola and "a large amount of maize was bought from abroad" (Valenčič 1977, 31-33, 48-9, 125).

In the Slovenian literature cited so far, mentions of maize imports in the second half of the eighteenth century are missing. Some information about maize trade in the Trieste seaport was published, although the data made available are not completely satisfactory, not least because the authors of such works posed different research questions than the ones we have here. The overall picture that we get from them is that maize trade can be detected in the form of import, export and transit, both by sea and land. In 1760, a very scarce amount of maize was "imported" through Trieste from Dalmatia, its destination being Austria (the Vienna area): maize was among the very last goods according to value (153rd out of 156), a trifling amount compared to the total (12 florins : 5.3 million Fl., transit excluded, Erceg 1970, 29, 69). In any case, no import to the Slovenian lands was registered in that year, nor data on maize transit trade in Trieste (Erceg 1970, 151). Five years later, we get a completely different picture of maritime transit trade (from abroad to abroad) through Trieste. In 1765, over one million pounds (1,060,400 Pfund) of maize were registered arriving from "Italy" with the destinations "Genoa, Lisbon, Messina, Livorno, and Dalmatia", meaning the considerable amount of nearly 60,000 tons, which represented $27 \%$ of the total weight and $7 \%$ of the total value of transited goods. ${ }^{5}$

In the next year, 67,890.5 stara of wheat, 13,599 of maize, 1,582 of barley, 780 of rye, and 251 of oats were "exported" by sea through Trieste (JanuaryOctober 1766). The destinations of these cereals were the nearby Venetian 
and Austrian northern Adriatic towns, but much more so the Italian Peninsula (the Po River mouth area, the Papal States, Ancona, Genoa, Civitavecchia, Livorno and probably Apulia). As far as maize is concerned, its (specified) destinations were Malta (1,701 stara), Koper (100 stara), Rijeka area (50 stara), Monfalcone (25 stara), and, last but not least, San Giovanni near Duino with 1,190 stara. ${ }^{6}$ The latter was a small port that traditionally supplied the Classical Karst, the city of Gorizia and the countryside, and the mountains along the Isonzo Valley, meaning that these 100,00o litres of maize (assuming these stara were Venetian) were probably intended for rural consumption in these areas.

The origin of the maize exported through Trieste in that year (1766) is not reported, but in general the cereals from Hungary and the Banat reached Trieste via Ljubljana, while the other route was through Karlovac to Rijeka (Andreozzi 2019, 55, 60, 62, 66). In both cases it is very likely that the first part of the transport was carried out along the Sava River which reaches both Zagreb (then the land route to Rijeka) and Ljubljana (then the land route to Trieste). We shall notice that the more costly land route from Zagreb to Rijeka is about twice as long as that from Ljubljana to Trieste, making the latter presumably more convenient. For these reasons, we may assume that maize, same as the other cereals, also arrived to Trieste and Rijeka at least partly from "Hungary" (comprising the Banat, the present-day Serbia and Romania). In evaluating this hypothesis, it may be considered that maize had been cultivated in the Sava and Danube basin area (Slavonia, Serbia) at least since the seventeenth century, if not earlier: in 1611-12 it is mentioned in Požega (now Croatia, some $20 \mathrm{~km}$ from the Sava River), while in 1722 in Serbia as much as $31 \%$ of the cereal-growing land was cultivated with maize (and 50\% with wheat, Stoianovich 1966, 1027-1028).

This Sava hypothesis is strengthened by the fact that half a century later (1817-22) consistent amounts of maize were imported to Ljubljana from the south via the Sava River waterway (Valenčič 1977, 68). Apart from this probable mainland route, during the year 1766 additional 16,996 stara of wheat, 61,452 of maize, 1,225 of barley, 1,860 of rye, and 8,013 of oats of unspecified provenience arrived to Trieste by sea. Later on (1782), Trieste exported maize to the Levante, while wheat was arriving from Lombardy and the Province of Ferrara in Italy (Andreozzi 2019, 60, 68), and in 1873 the export by sea of "wheat, rye and maize" continued (Panjek G. 2003, 275).

6 I wish to thank Daniele Andreozzi for the additional information he gave me on these quantities; see his article cited below. 


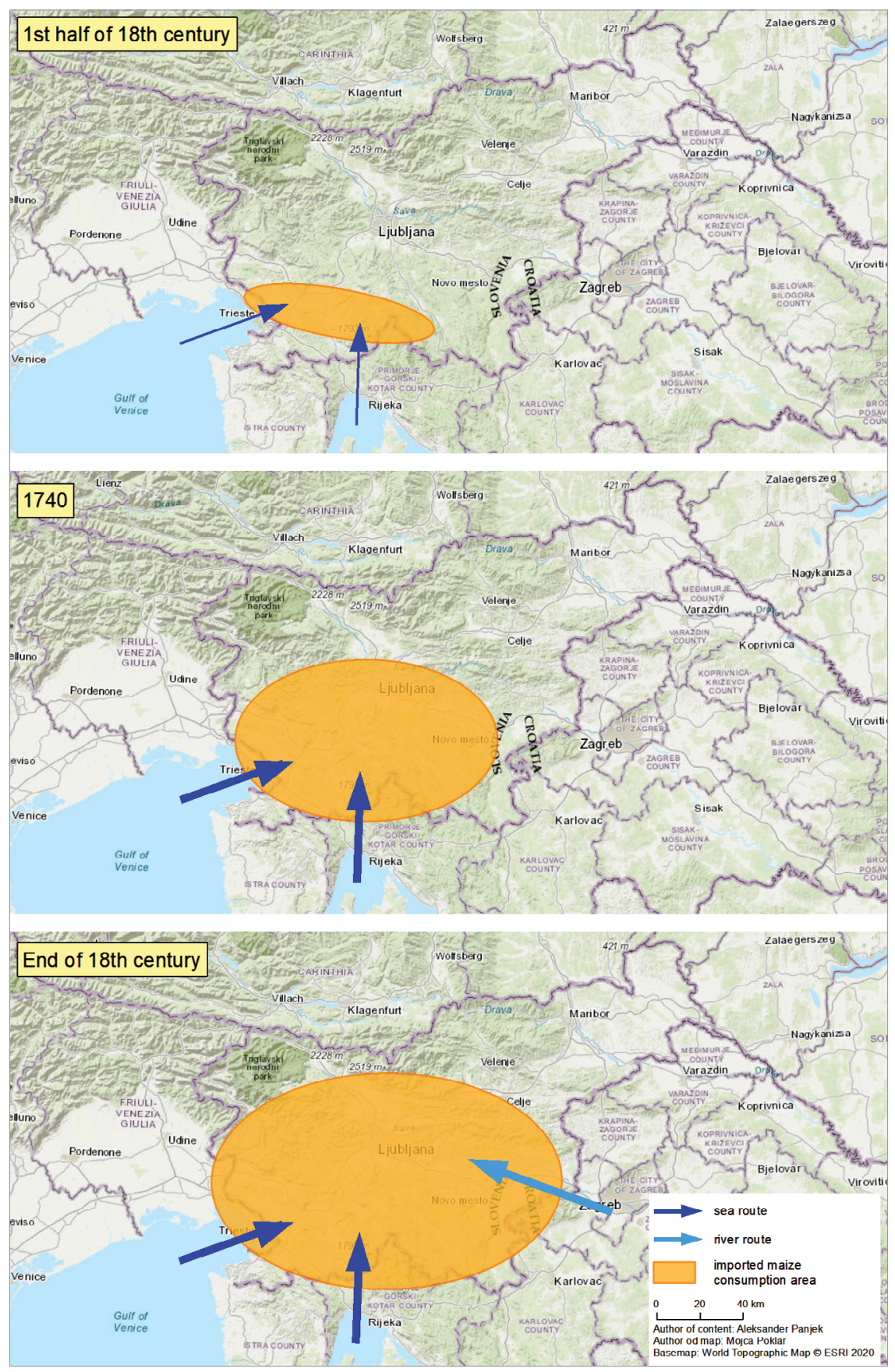

Map 3. Maize import directions in the eighteenth century (sea and river). 
Our task here is to outline a chronological and a geographic pattern of maize trade imports to Slovenian lands, and not of the maize sea trade in the Adriatic and the Mediterranean. That makes it perhaps a bit easier for us to trace a couple preliminary conclusions that comprise the above-mentioned Sava hypothesis. The proveniences of maize imported via the Adriatic seaway through Trieste and Rijeka in the eighteenth century may be simplified as follows: The Republic of Venice and the Papal States from the southwest, and the Balkan regions (including Dalmatia) and Turkish lands from the southeast. In addition, there was the Sava River waterway quite likely bringing in maize from Hungary (comprising Croatia) and the Banat (inland Balkans, Serbia). Consequently, the second preliminary conclusion may be that a maize trade route of Pannonian provenience transited through Slovenian and Croatian lands towards the Adriatic ports. This may well have influenced the availability of maize for the local population. Much the same may be said about Trieste becoming a seemingly relevant Adriatic "hub" not only for cereals in general (Andreozzi 2019, 60, 69) but also for maize in particular. Such development of Trieste as an important regional centre in the cereal trade is parallel with that of Ljubljana in the inland. During the eighteenth century, Ljubljana strongly increased its role as a grain market place for a wider regional area, while trade passed from the hands of peasants into those of merchants. The grain imported from Hungary and Croatia was not meant to supply the needs of the city alone, but was directed further towards the Port of Trieste and exported. This was a period of a great development of grain trade in Ljubljana, which lasted until the railway construction (mid-nineteenth c.) that allowed a direct flow of Hungarian grain to the seaport of Trieste (Valenčič 1977, 4-5, 9, 27). This means that in the eighteenth century the Slovenian lands could count on two growing cereal-trade centres, Ljubljana and Trieste, with a capacity that exceeded the local needs and could supply maize provisions by land and sea.

The first impression we obtain from the rather short price series in Table 2 is that, at the end of the eighteenth century, maize in Ljubljana was unsurprisingly cheaper than wheat, yet not that much so if compared to other cereals, for example rye and buckwheat, which were common in the unwealthy and rural people's diet in Slovenian regions. Since the series is not only very short but also coinciding with the price instability of the 'French years', I would not interpret them further before more research is conducted on this aspect. 
Table 2. Cereal prices in Ljubljana at the end of the eighteenth century: yearly averages for ı०o litres in Austrian florins*

\begin{tabular}{lcccc} 
& 1795 & 1796 & 1797 & 1798 \\
\hline Wheat & 4.69 & 6.62 & 6.07 & 5.88 \\
\hline Rye & 4.51 & 4.70 & 4.37 & 4.17 \\
\hline Barley & 3.79 & 4.07 & 4.02 & 4.01 \\
\hline Oats & 2.79 & 2.72 & 2.91 & 3.38 \\
\hline Buckwheat & 3.21 & 4.24 & 5.70 & 4.51 \\
\hline Millet & 4.36 & 4.54 & 4.52 & 4.24 \\
\hline Maize & 4.15 & 4.52 & 3.85 & 4.29 \\
\hline Maize price index compared to & & 63.4 & 73.0 \\
\hline Rheat (=100) & 88.5 & 68.3 & 88.1 & 102.9 \\
\hline Buckwheat (=100) & 92.0 & 96.2 & 67.5 & 95.1 \\
\hline
\end{tabular}

* Convention value, I Fl. = II.69 g of silver; calculation based on monthly averages in Valenčič 1977, 157-159.

\section{Interpretive conclusions and hypotheses: chronology and trajectories of diffusion}

With these considerations about maize trade in the eighteenth century, we have somehow already anticipated the last part of this contribution, which is dedicated to conclusions and interpretations based on the information gathered so far. Starting with the chronology of diffusion, we have noticed how at the end of the sixteenth and the beginning of the seventeenth centuries the Slovenian regions seem to be surrounded by early mentions of maize cultivation and trade, while in the present territory of Slovenia such examples are lacking. The question is whether this reflects the historical situation or perhaps more so the state of research. A basic observation may be that while Austrian historians have engaged in tracing the earliest mentions and early evidence of the presence of maize, Slovenian historians have not concentrated specifically on maize, dedicating most of their attention to central Slovenia (Carniola), where maize had a later and more scarce diffusion, and to the richer eighteenth-century sources. This may be the reason why we lack more archival evidence about maize in Slovenia, and its western part in particular, for most of the period until the eighteenth century. Something Austrian and Slovenian historians have in common is that 
both understand the naming of maize in the people's local tongue as an indicator of its provenience, where sirek would signal an "Italian" direction of diffusion (sorgo turco), while turščica, kukuruz, türkische Koch and Türkensterz would mean a "Turkish" (Balkan) origin.'

Nevertheless, Slovenian historians agree on the location of the first region where maize was cultivated and consumed in the south-western area, but without giving a precise time frame. At present, based on the viewed evidence, it seems that in western Slovenia in the first half of the seventeenth century maize was known but not yet a relevant presence in the fields and on the tables, with the possible (still hypothetical) exception of Trieste and Gorizia with their close surroundings. Somehow contrary to the so far accepted, although loose periodization, we have more evidence of the presence of maize in the first half of the seventeenth century from the eastern part of the Slovenian lands, in Styria, especially in and around Graz. The still small detected amounts do not really allow the conclusion that maize had already become an important crop or a relevant foodstuff, nor that it was present in the Slovenian-speaking area of the time or the present-day Slovenia. All in all, we may conclude that there were two areas, the east and the west, where maize diffusion ran independently from each other and perhaps even earlier in the eastern than in the western Slovenian lands. In the second half of the seventeenth century, maize is detected in a third region, i.e. southern Slovenia, but in restricted areas and with a very uneven, interspersed diffusion; however, where there was more, maize started entering the peasant diet. The same is true of the western and eastern regions: where maize is present as a cultivar, it starts having a greater role in the peasant diet, in the form of porridge and bread.

In the first half of the eighteenth century, we may observe three phenomena. On the one hand, maize is affirmed as an important crop and a popular foodstuff in the areas where it was present already before that time, with a possible geographical extension of the original narrow and interspersed diffusion areas. This is valid for the two main areas, east and west, while in southern Slovenia maize is lagging behind and remains an outsider crop and foodstuff. Thirdly, it is in this period that we have explicit and converging evidence of a relevant import of maize as a foodstuff through the Adriatic ports, especially in the years of scarcity - meaning

$7 \quad$ The way maize was named has been considered a sign of its origin and direction of diffusion for a long time. On the many names it had in the Balkan region and their possible meanings see Stoianovich 1966. 


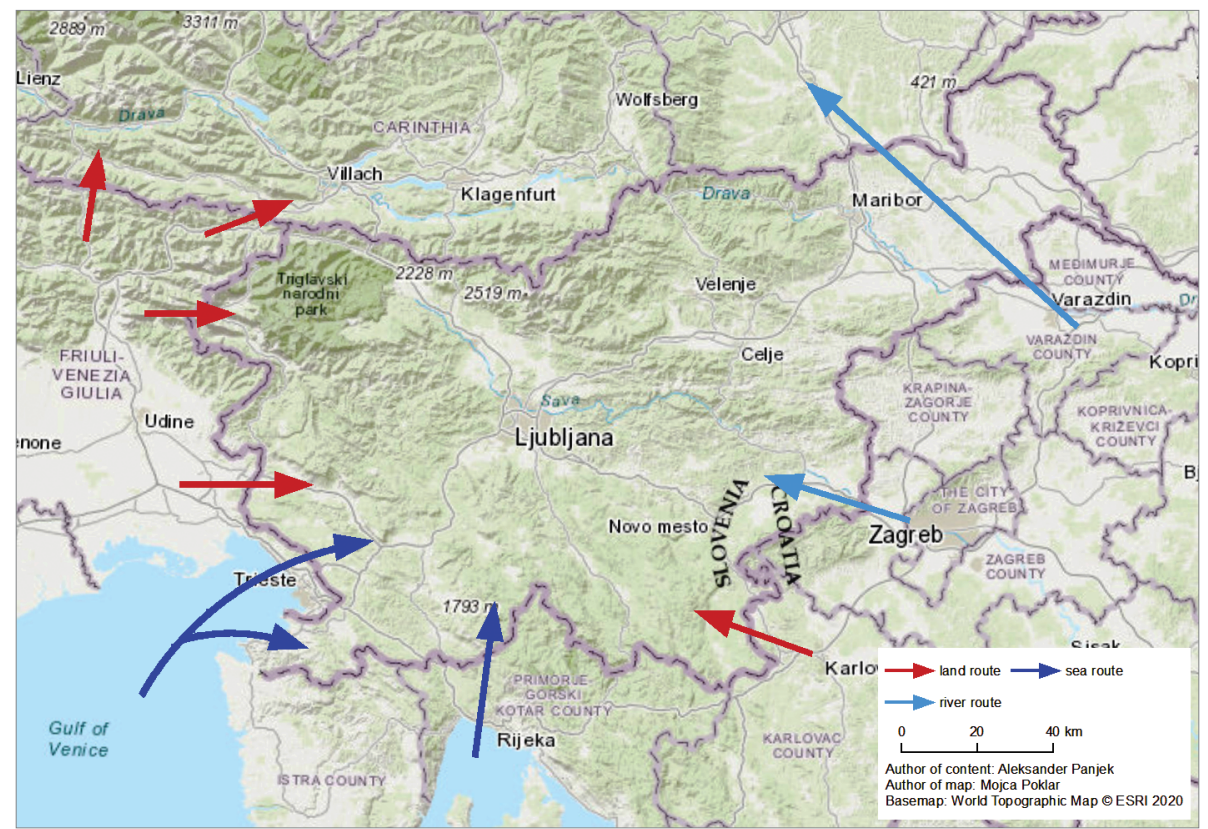

Map 4. Maize's gateways to Slovenian regions (sixteenth-eighteenth c.)

that it gained importance in the diet of the western region faster than it progressed in the fields. The second half of the eighteenth century marks a large and definitive affirmation of maize in both the east and west, with an attested relevant diffusion in the fields and omnipresence on the peasant tables. In central Slovenia, on the contrary, maize becomes a foodstuff in times of crisis and nothing more.

Just as in the case of timing, we may add some details to the directions via which maize entered the Slovenian lands. The prevailing picture of the trajectories of maize diffusion is indeed already half a century old and it goes as follows: "In the Gorizia region, maize spread under Venetian influence (named sirk from the Italian sorgo); in Carniola it was established only in some places in Dolenjska (as turščica, turška pšenica - Turkish wheat); but most of all they started to sow it in Styria, where it had arrived from Hungary in the seventeenth century (under the name kukurutz)" (Gestrin 1969, 3). The evidence we have collected allows us to agree with Gestrin on this, as well as with Valenčič, who wrote that maize came to the Slovenian lands independently from the West, that is from the Italian lands, and from the East or, as he put it, from "Turkey, Hungary and Croatia" (Valenčič 


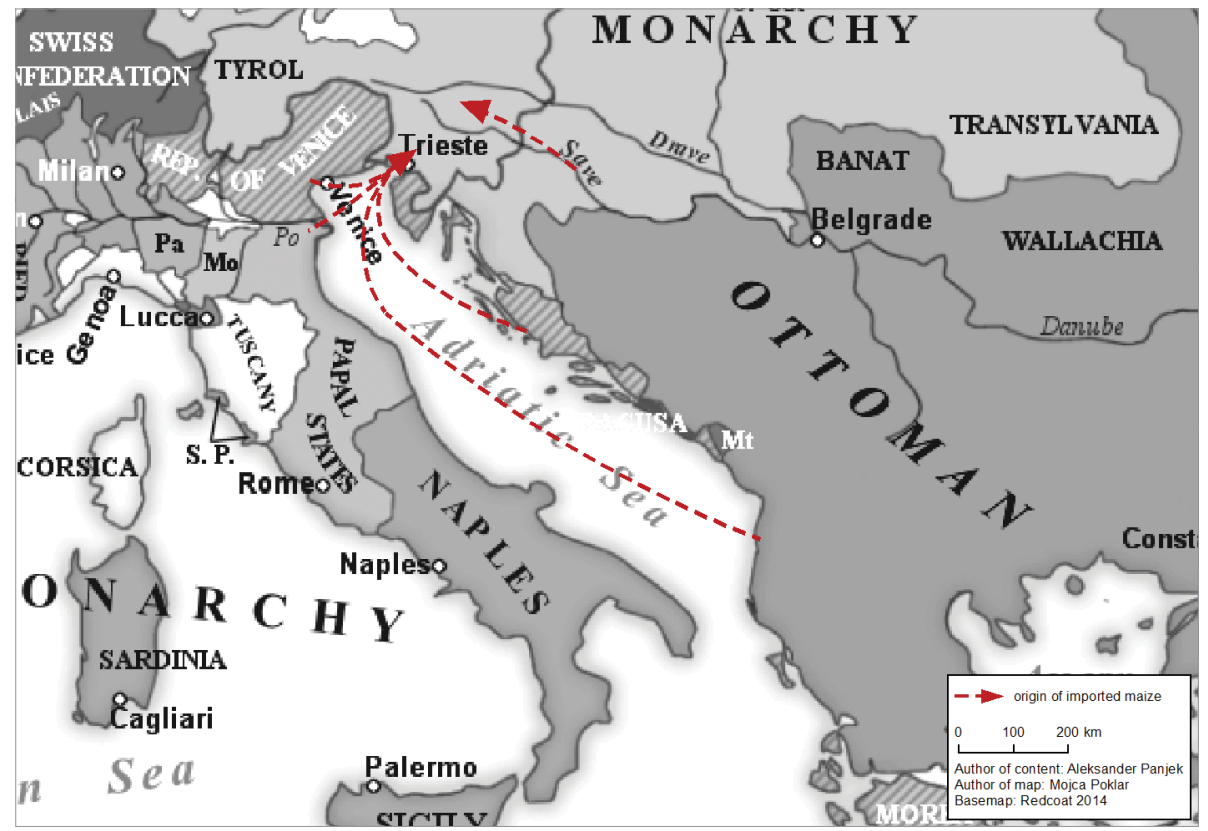

Map 5. Origin of imported maize (eighteenth c.)

1970, 258-9). Valenčič meant that maize appeared in Styria later than in the West, but we have seen that this is not necessarily confirmed by the existing evidence; rather the opposite seems to be true or, at most, a parallel process might be hypothesized.

Going back to the trajectories, it is probably more precise to speak of a south-western and a south-eastern direction of maize diffusion into the Slovenian lands, rather than of an "East" and "West" one. Moreover, I would propose a reading that is a little more complex than the "Venetian" and "Hungarian" influence. One gateway was from the southwest and it comprised mainland routes from Venetian Friuli and sea routes through the Adriatic ports of Trieste and Rijeka. Moreover, such maize did not come by boat only from the Venetian mainland territories, but most likely from the Papal States as well, as Valenčič seems to suggest by using the term "Italy". In fact, it is known from Gestrin's studies that at least since the Late Middle Ages and in the early modern period the Austrian Habsburg ports of Trieste and Rijeka had intense maritime trade connections with the western Adriatic coast (the Marche region in particular), not least to escape the Venetian navigation monopoly (Gestrin 1975; 1991, 113, 156-158). In addition to that, the maize entering by sea routes might as well have 
arrived from the eastern Adriatic coasts and the eastern Mediterranean (Dalmatia and "Turkish regions"). The other main maize gateway into Slovenia was from the Balkan mainland to the eastern part of Styria, where the rivers very likely played a role. Evidence confirms this route and the role of river navigation in the eighteenth century, but we may assume this was also the case in earlier periods. That is, if we consider the opportunities provided by the river routes, which in the early modern period connected the Slovenian lands to the Black Sea region (Vilfan 1978, 79): I am thinking of the Danube (for today's Serbia and Hungary) and its tributary rivers Sava, Drava and Mura (for today's eastern Croatia, eastern and central Slovenia, and south-eastern Austria). This would mean that maize came to the eastern Alpine and subalpine area both from the west-southwest and the southeast, as German-language literature has been telling us since the sixteenth century. The addition to be made is that in both directions, maize arrived by land as well as by sea (as the stronger presence around the port towns shows), while we may imagine the rivers playing a role in the land route.

\section{Interpretive conclusions: the factors of maize diffusion}

By connecting the conclusions mentioned so far, and combining them with some existing interpretations about the conditions of maize diffusion by historians, I would propose the following updated interpretation of the factors of maize diffusion. To this purpose, I will distinguish between socioeconomic factors and localization factors as follows:

\section{a) Socioeconomic factors}

The Austrian historians Roman Sandgruber and Walter Brunner wrote that of crucial importance for the affirmation of maize in Vorarlberg and Styria during the seventeenth century must have been the worsening living conditions among the peasantry, who realized that maize granted very good yields and large harvests, and therefore started to increase its cultivation. Extending this interpretation to the Slovenian regions, I would add that - perhaps - only the hardship caused by the economic stagnation and crisis in the long period between the mid-seventeenth and mid-eighteenth centuries, made it reasonable for the peasants to engage in the hard and time-consuming work necessary for maize cultivation with the techniques used at that time. 
b) Localization factors

Both Slovenian and Austrian historians point out the importance of the climatic factor influencing and limiting the diffusion of maize, in particular because throughout the eighteenth century no varieties were present which could be successfully cultivated in less warm areas. That is why in the earlier phase maize diffusion coincided quite precisely with the areas where vines would grow, and vines and maize were cultivated together. We could agree with this, but based on the evidence presented it seems sensible to upgrade the factors influencing the localization of maize cultivation in the region between the eastern Alps and the Adriatic, as stated below. By considering the shared features of the areas where maize first spread and became established, we may notice they were:

- Climatically suitable (summer and autumn warmth): localization factor 1 .

- Located in lowlands and flatlands (plains and valley bottoms): localization factor 2 .

- $\quad$ By water streams (large or small): localization factor 3.

- Along transit routes connected to areas where maize was already present (roads, Alpine passes, seaports, rivers): localization factor 4.

c) The 'potato factor' and the tripartition of Slovenia at the end of the eighteenth century.

Lastly, we may perhaps identify another factor influencing the diffusion of maize. Slovenian historians have identified a factor that limited the affirmation of maize in Slovenia in general, the rushed diffusion of the potato in the eighteenth century. The success of the potato would have hindered the affirmation of the other 'new food for the poor', i.e. maize. However, considering the evidence we have collected about the western and eastern Slovenian lands, we may conclude that this may be true for central Slovenia only and not for the whole country. We may therefore propose a tripartition of Slovenia by the end of the early period of the affirmation of the two new cultures (late eighteenth century), in which maize prevailed in the west and in the east, while the potato dominated central Slovenia.

It is fairly possible that I have overlooked some article or publication, but exhaustiveness was not among my primary goals. That said, I believe only renewed research on primary sources could help to draw a more precise picture of the dynamics and factors of the rooting of maize in Slovenia. 


\section{Bibliography}

\section{Literature}

Andreozzi, D. 2019. 'Laggravio dei dazi». Norme, mercato e concorrenze nei circuiti del grano della Trieste settecentesca.' In La polizia de' grani. Mercati, regale e crisi di sussistenza nelle economie di Antico Regime, edited by A. Clemente and S. Russo, 53-71. Catanzaro: Rubettino Editore.

Britovšek, M. 1958/59. 'Uvajanje novih kultur na Kranjskem v drugi polovici 18. in prvi polovici 19. stoletja.' Zgodovinski časopis 12/13: 111-149.

Britovšek, M. 1964. Razkroj fevdalne agrarne strukture na Kranjskem. Ljubljana: Slovenska matica.

Brunner, W. 1994. 'Frühe Nachrichten über Maisanbau in der Steiermark.' Blätter für Heimatkunde 68: 5-15.

Cavazza S., P. Iancis, and D. Porcedda. 2003. Studi e documenti su Carlo Morelli e l'Istoria della Contea di Gorizia. Gorizia: Edizioni Laguna.

Czoernig, C. von 1873. Il territorio di Gorizia e Gradisca, 1873. Re-print Milano: Cassa di Risparmio di Gorizia, 1969.

Erceg, I. 1970. Trst i bivše habsburške zemlje u međunarodnom prometu. Građa za gospodarsku povijest Hrvatske, 15. Zagreb: Jugoslovenska akademija znanosti i umjetnosti.

Fakin Bajec, J. 2015. 'Furlanska koruza in polenta v poljedelski in kulinarični tradiciji Zgornje Vipavske doline.' Izvestje Raziskovalne postaje ZRC SAZU Nova Gorica 12: 23-29.

Gestrin, F. 1969a. 'Oris gospodarstva na Slovenskem v obdobju zgodnjega kapitalizma.' Kronika 17 (1): 1-8.

Gestrin, F. 1969b. 'Oris gospodarstva na Slovenskem v obdobju agrarne revolucije in prevlade manufakturne proizvodnje.' Kronika 17 (2): 65-71.

Gestrin, F. 1975. 'Trgovina slovenskih dežel z italijanskimi ob koncu srednjega veka in v 16. stoletju.' Zgodovinski časopis 29 (1-2): 45-76.

Gestrin, F. 1991. Slovenske dežele in zgodnji kapitalizem. Ljubljana: Slovenska matica.

Hacquet, B. 1801. Abbildung und Beschreibung der Südwest- und östlichen Wenden, Illyrer und Slaven. Leipzig.

Ivetic, E. 1999. L'Istria moderna. Un'introduzione ai secoli XVI-XVIII. TriesteRovigno: Centro di Ricerche storiche Rovigno. 
Makarovič, G. 1986. 'Kuhinjska oprema, kuhinje, kuharice in prehrana v XVII. stoletju na Slovenskem.' Glasnik etnografskog muzeja u Beogradu 50: $42-72$.

Morelli, C. 1855. Istoria della Contea di Gorizia, II. Gorizia 1855. Re-print edited by S. Cavazza, P. Iancis and D. Porcedda. Gorizia, Edizioni Laguna, 2003.

Panjek, A. 2011. 'Not demesne but money: lord and peasant economies in early modern western Slovenia.' Agricultural History Review 59 (2): 293-311.

Panjek, A. 2018: 'Kruh naredi človeka: kdo je kdaj sit na primorskem podeželju v 17. in 18. stoletju.' In Lakote in pomanjkanje: slovenski primer, edited by M. Šorn, 25-41. Ljubljana: Inštitut za novejšo zgodovino.

Panjek, G. 2003. 'Una “commercial officina” fra vie di mare e di terra.' In: Storia economica e sociale di Trieste, II, La città dei traffici 1719-1918, edited by R. Finzi, G. Panjek and L. Panatriti, 235-348. Trieste: LINT.

Pferschy, G. 1976. 'Die Verbreitung des Weizen- und Maisbaues um 1787.' In Atlas zur Geschichte des Steirischen Bauerntums, by F. Posch, M. Straka, and G. Pferschy, Map 27. Graz: Akademishes Druck- und Verlaganstalt.

Rutar, S. 1882: Zgodovina Tolminskega. Gorica, re-print Nova Gorica: Goriški muzej, 1972.

Sandgruber, R. 1982. Die Anfänge der Konsumgesellschaft. Konsumgüterverbrauch, Lebensstandard und Alltagskultur im Österreich im 18. Und 19. Jahrhundert. Wien: Verlag für Geschichte und Politik.

Stoianovich, T. 1966. 'Le mais dans le Balkans.' Annales. Ėconomie, Sociétés, Civilisations 21 (5): 1026-1040.

Valenčič, V. 1970. 'Kulturne rastline.' In Gospodarska in družbena zgodovina Slovencev. Zgodovina agrarnih panog, I, 251-272. Ljubljana: Slovenska akademija znanosti in umetnosti.

Valenčič, V. 1977. Žitna trgovina na Kranjskem in ljubljanske žitne cene od srede 17. stoletja do prve svetovne vojne. Razprave X (4). Ljubljana: SAZU.

Vilfan, S. 1978. 'Transportni stroški okrog leta 160o.' Acta historico-oeconomica Iugoslaviae 5: 79-88.

\section{Web sources}

Redcoat Rebel. 2014. Europe at the beginning of the $18^{\text {th }}$ century. Historical map. Creative commons CC BY-SA 3.0. 